\title{
Environmental and technology policies for climate mitigation
}

\author{
Carolyn Fischer ${ }^{\mathrm{a}}$, Richard G. Newell ${ }^{\mathrm{a}, \mathrm{b}, *}$ \\ ${ }^{\text {a }}$ Resources for the Future, Washington, DC, USA \\ ${ }^{\mathrm{b}}$ Nicholas School of the Environment and Earth Sciences, Duke University, Box 90227, Durham, NC 27708, USA
}

Received 28 June 2005

Available online 7 November 2007

\begin{abstract}
We assess different policies for reducing carbon dioxide emissions and promoting innovation and diffusion of renewable energy. We evaluate the relative performance of policies according to incentives provided for emissions reduction, efficiency, and other outcomes. We also assess how the nature of technological progress through learning and research and development (R\&D), and the degree of knowledge spillovers, affects the desirability of different policies. Due to knowledge spillovers, optimal policy involves a portfolio of different instruments targeted at emissions, learning, and R\&D. Although the relative cost of individual policies in achieving reductions depends on parameter values and the emissions target, in a numerical application to the U.S. electricity sector, the ranking is roughly as follows: (1) emissions price, (2) emissions performance standard, (3) fossil power tax, (4) renewables share requirement, (5) renewables subsidy, and (6) R\&D subsidy. Nonetheless, an optimal portfolio of policies achieves emissions reductions at a significantly lower cost than any single policy.
\end{abstract}

(C) 2007 Elsevier Inc. All rights reserved.

JEL classification: Q21; Q28; Q48; O38

Keywords: Technology; Externality; Spillover; Learning; R\&D; Policy; Climate change; Renewable energy

\section{Introduction}

To reduce greenhouse gas emissions and promote technological development and diffusion of renewable energy, recent policies and proposals employ a broad range of incentives. Some policies create disincentives for emitting energy sources by taxing these energy sources or by making greenhouse gas emissions expensive, such as with a tradable emissions permit system, a tax on carbon dioxide $\left(\mathrm{CO}_{2}\right)$, or an emissions intensity standard for generation. Alternatively, others try to ensure viable markets for the environmentally desirable technology, such as a generation subsidy for renewable energy or a portfolio (market share) requirement for renewable sources. Still other policies focus on reducing the cost of research and development (R\&D) and of investment, such as a tax credit for R\&D or subsidies for capital costs. Similar policy initiatives are growing not only for

\footnotetext{
*Corresponding author. Nicholas School of the Environment and Earth Sciences, Duke University, Box 90227, Durham, NC 27708, USA. Fax: + 19196845833.

E-mail address: richard.newell@duke.edu (R.G. Newell).
} 
renewables, but also for relatively clean coal technologies, advanced nuclear power, and a range of technologies in the transportation sector.

Much attention is being given particularly to the potential for renewable energy to displace fossil-fueled sources. In 2001, renewable energy sources provided $5.7 \%$ of the total primary energy supply for OECD countries, with $54 \%$ coming from combustible renewables and waste (i.e., biomass, but not trash and nonrenewable waste), $35 \%$ by hydropower, and $12 \%$ by geothermal, solar, wind, and tide energy [20]. For electricity generation, renewables represented $15 \%$ of production worldwide, but only $2.1 \%$ if one excludes hydro. Proposals in the United States aim to increase renewable electricity production to $15 \%$ by 2020 , while the European Union has a target to produce $22 \%$ of electricity and $12 \%$ of gross national energy consumption from renewable energy by 2010 [21]. Given such ambitious targets, a great deal of focus has been placed on the role of innovation in lowering the cost of these nonemitting energy sources.

Although economists typically argue that a direct price for $\mathrm{CO}_{2}$ (via a tax or tradable permit system) would provide the most efficient incentives for development and use of less emitting technologies, the diversity of the present policies suggests that other forces are at play. First of all, emissions pricing policies that risk significantly reducing economic activity among energy-intensive sectors have little political appeal. Second, raising the price of $\mathrm{CO}_{2}$ can have important distributional consequences, both for owners of fossil-fueled generation sources and for consumers. Third, innovation market failures, such as spillover effects, imply that emissions pricing alone will not provide sufficient incentive to improve technologies. Credibility problems may also arise in using a promise of high future emissions prices to boost current innovation, since such high prices may no longer be desired if and when the resulting cost reductions arrive (see [27,32]). Finally, the innovation process may occur not only through R\&D investments, but also via learning through the production and use of new technologies; thus, encouraging output may spur innovation. Consequently, output support and other subsidies are often attractive to decisionmakers alongside emissions regulations and R\&D policies.

The environmental economics literature on induced innovation has focused on the role of environmental policy in stimulating innovation in environmentally friendly technologies [23], including the effects of energy price changes and regulations on innovations in energy technologies [36,41], and the efficacy of market-based environmental policies relative to prescriptive regulation in inducing efficient innovation [6,30,46]. Among different market-based instruments, innovation and adoption incentives may also differ (e.g., [3,13,26,31,44]). However, these studies have primarily focused on comparing emissions pricing policies, like emissions taxes and auctioned or grandfathered permits, rather than a more pragmatic, broader set of policies such as those using performance standards and supporting renewable energy.

The treatment of technological change is also important in models for assessing the impact of climate change policies [5]. While most modeling efforts assume exogenous technical change, the small number of climate-energy models that incorporates induced technological change varies in terms of their technological detail, whether they focus on technological progress as a function of learning by doing or R\&D investments, and the degree to which they have an economic structure capable of computing welfare effects [42]. On the policy front, models tend to focus on policies that change the price of emissions, such as $\mathrm{CO}_{2}$ taxes or tradable permits. For example, Goulder and Mathai [15] model technological innovation through both R\&D investments and learning by doing in the context of optimal carbon taxes: while the two formulations differ, the optimal tax is essentially the same.

In this paper, we bridge several areas in the analysis of climate policies and induced innovation. We consider a broad set of environmental policies, including indirect ones, and incorporate "knowledge investment" through both learning by doing and R\&D. We identify six of the main policy options for reducing greenhouse gas emissions in the electricity sector and evaluate their relative performance according to different potential goals: emissions reduction, renewable energy production, $R \& D$, and economic surplus. We also assess how the nature of technological progress - the degree of knowledge spillovers and the degree of innovation occurring through learning by doing or R\&D - affects the desirability of different policies.

Some clear principles emerge. We find that when the ultimate goal is to reduce emissions, policies that create incentives for fossil-fueled generators to reduce emissions intensity, and for consumers to conserve energy, perform better than those that rely on incentives for renewable energy producers alone. Overall, we find that the nature of knowledge accumulation is far less important than the nature of the policy incentives. This is consistent with [39], where the welfare gains from correcting environmental externalities are more important 
for policy than the gains from technological change. For the type of moderate emissions targets we explore, a renewable energy $R \& D$ subsidy turns out to be a particularly inefficient means of emissions reduction, since it postpones the vast majority of the effort to displace fossil-fueled generation until after costs are brought down. A similar result was found by Schneider and Goulder [45] employing a CGE approach. This requires very large R\&D investments and forgoing near-term cost-effective abatement opportunities. While climate change is a long-term problem, the results for mid-term strategies emphasize the important role for policies that encourage abatement across all available forms and timeframes, as well as the limitations of narrowly targeted policies - particularly those focused solely on R\&D.

Nonetheless, given the presence of more than one market failure - an emissions externality and knowledge spillovers - no single policy can correct both simultaneously; each poses different trade-offs [24]. The presence of knowledge spillovers means that separate policy instruments are necessary to optimally correct the climate externality and the externalities for both learning and R\&D. In fact, we find that an optimal portfolio of policies can achieve emissions reductions at a significantly lower cost than any single policy (as in [45]), although the emissions reductions continue to be attributed primarily with the emissions price.

Together, these results illuminate some of the arguments in Montgomery and Smith [32] that R\&D is the key for dealing with climate change and that an emissions price high enough to induce the needed innovation cannot be credibly implemented. We show that an emissions price alone, although the least costly of the single policy levers, is significantly more expensive alone than when used in combination with optimal knowledge subsidy policies. Although a high future emissions price may not be credible, with the combination policy the required emissions price is much more modest. However, if one believes that even a modest emissions price is not politically feasible, an R\&D subsidy by itself is not the next best policy, and the costs of that political constraint are likely to be quite large and increasing with restrictions on the remaining policy options. It should be kept in mind, however, that we focus on reductions over the near-to-mid-term and incremental improvement of existing technology, rather than breakthrough technologies that might achieve deep reductions. It seems likely that $R \& D$ policies have greater salience in the latter context, although this lies beyond the scope of the current paper.

\subsection{Alternative environmental and technology policies}

Among the OECD countries, policies to reduce greenhouse gas emissions and support renewable energy vary widely, both in form and in degree. We distinguish six policies. First, a $\mathrm{CO}_{2}$ emissions price provides incentives to reduce $\mathrm{CO}_{2}$ intensity and makes fossil-fueled sources relatively more expensive compared to renewables. Several Scandinavian countries have $\mathrm{CO}_{2}$ taxes, and in 2005 the European Union launched a program of tradable $\mathrm{CO}_{2}$ emissions permits.

Second, a tax on fossil-fueled energy seeks to discourage use of these sources in favor of renewables. The United Kingdom, Germany, Sweden, and The Netherlands tax fossil-fueled sources, in most cases by exempting renewable sources from an energy tax. Third, a tradable emissions performance standard sets the average emissions intensity of fossil and renewable output combined. Although less frequently discussed for promoting renewable energy in electricity generation, it does arise in climate policies for energy-intensive industries, such as for certain sectors in the United Kingdom's climate change levy.

Fourth, so-called portfolio standards for renewable sources are a popular form of support. These market share requirements - also known as quota obligations, green certificates, and the like - may require either producers or users to derive a certain percentage of their energy or electricity from renewable sources. Such programs have been planned or established in Italy, Denmark, Belgium, Australia, Austria, Sweden, and the United Kingdom; a range of portfolio standards for electricity generation are in operation in at least 18 of the U.S. states and the District of Columbia. Fifth, a production subsidy for renewable energy improves the competitiveness of these sources vis-à-vis fossil fuels. The United States has the renewable energy production incentive of $1.9 \mathrm{cent} / \mathrm{kW} \mathrm{h}$ and 24 individual U.S. states have their own subsidies. Canada also has a market incentive program and several European countries (Germany has been particularly supportive), as well as Korea, have production subsidies.

Finally, subsidies for $R \& D$ investment in renewable energy are common, including government-sponsored research programs, grants, and tax incentives. Major programs exist in the United States, the United Kingdom, 
Denmark, Ireland, Germany, Japan, and The Netherlands. R\&D subsidies are used to encourage both nearterm improvements, as with $\mathrm{R} \& \mathrm{D}$ tax credits and commercialization incentives, and long-term innovations through targeted research.

\section{Model}

We develop a unified framework to assess the six different policy options for reducing greenhouse gas emissions and promoting the development and diffusion of renewable energy in the electricity sector. This focus reflects both the great deal of policy attention devoted to this sector, which accounts for two-fifths of $\mathrm{CO}_{2}$ emissions, and the availability of data to parameterize the model. However, the qualitative results will still offer intuition for other sectors as well as a broad-based program to reduce $\mathrm{CO}_{2}$.

The stylized model is deliberately kept simple to highlight key features. It includes two subsectors, one emitting (fossil fuels) and one nonemitting (renewables), and both are assumed to be perfectly competitive and supplying an identical product, electricity. ${ }^{1}$ Fossil-fueled production includes a $\mathrm{CO}_{2}$-intensive technology (coal) that operates primarily as a baseload and a lower-emitting technology (gas turbines) that dominates at the margin. To the extent that renewable energy is competitive, it displaces marginal fossil-fueled generation. We therefore treat nuclear- and hydro-based generation as fixed in response to the range of policies we model, a reasonable assumption based on other detailed models (see the Numerical application). The model has two stages, each representing a specific number of years. Electricity generation, consumption, and emissions occur in both stages, while investment in knowledge takes place in the first stage and, through technological change, lowers the cost of renewables generation in the second. An important assumption is that firms take not only current prices as given, but also take prices in the second stage as given, having perfect foresight about those prices.

To allow for consideration of the length of time it takes for innovation to occur, and for the lifetime of the new technologies, let the first and second stages be made up of $n_{1}$ and $n_{2}$ years, respectively. For simplicity, we assume that no discounting occurs within the first stage; this assures that behavior within that stage is constant. However, let $\delta$ represent the discount factor between stages. It is possible to allow for discounting within the second, longer stage by altering $n_{2}$ to reflect such a discounting; in that case $n_{2}$ can be thought of as "effective" years.

\subsection{The emitting fossil-fueled sector}

The emitting sector of the generation industry, denoted with superscript $\mathrm{F}$, relies on two fossil fuels for production: coal, $x$, and natural gas, $y$. Total output from the emitting sector is $f_{t}=x_{t}+y_{t}$ in year $t$. Total emissions from this sector equal

$$
E_{t}=\mu_{x} x_{t}+\mu_{y} y_{t}
$$

as each fuel has a fixed $\mathrm{CO}_{2}$ intensity $\mu_{i}$. Marginal production costs for natural gas- and coal-fired generation, $C_{y}^{\prime}(y)$ and $C_{x}^{\prime}(x)$, respectively, are assumed to be increasing in output $\left(C_{y}^{\prime \prime}(y)>0, C_{x}^{\prime \prime}(x)>0\right)$. The opportunities for $\mathrm{CO}_{2}$ abatement in electricity rely largely on fuel switching; although coal gasification or generation efficiency improvements are options, they tend to explain little of the predicted reductions in climate policy models (see, e.g., [10]).

Two policies affect the fossil-fueled sector directly: an emissions price and an output tax (which may be explicit or implicit, as with the portfolio standard discussed below). Let $\tau_{t}$ be the price of emissions (i.e., emissions tax or equilibrium permit price) and $\phi_{t}$ be the tax on fossil-fueled generation at time $t$, respectively. Other policies that stipulate quantity standards, such as renewables portfolio standards and emissions performance standards, will be specified in the following section, as they require some modifications to the

\footnotetext{
${ }^{1}$ Although large portions of the electricity sector remain regulated, policy-induced changes to marginal production costs are likely to be passed to consumers, and in a longer horizon a transition to deregulated markets is likely to make markets relatively competitive in the future.
} 
generalized model. In fact, the effects of performance standards for renewables and emissions can be represented by these twin taxes.

Profits for the representative emitting firm are

$$
\begin{aligned}
\pi^{\mathrm{F}}= & n_{1}\left(\left(P_{1}-\phi_{1}\right)\left(x_{1}+y_{1}\right)-C_{x}\left(x_{1}\right)-C_{y}\left(y_{1}\right)-\tau_{1}\left(\mu_{x} x_{1}+\mu_{y} y_{1}\right)\right) \\
& +\delta n_{2}\left(\left(P_{2}-\phi_{2}\right)\left(x_{2}+y_{2}\right)-C_{x}\left(x_{2}\right)-C_{y}\left(y_{2}\right)-\tau_{2}\left(\mu_{x} x_{2}+\mu_{y} y_{2}\right)\right),
\end{aligned}
$$

where $P_{t}$ is the price of electricity. The firm maximizes profits with respect to output from each fuel source yielding the following first-order conditions:

$$
\begin{array}{ll}
\frac{\partial \pi^{\mathrm{F}}}{\partial x_{t}}=0: \quad P_{t}=C_{x}^{\prime}\left(x_{t}\right)+\phi_{t}+\tau_{t} \mu_{x} \quad \text { and } \\
\frac{\partial \pi^{\mathrm{F}}}{\partial y_{t}}=0: \quad P_{t}=C_{y}^{\prime}(y)+\phi_{t}+\tau_{t} \mu_{y} .
\end{array}
$$

We assume an interior solution; although theoretically possible, no fuel will be completely driven out of the market in our scenarios. Together, Eqs. (3) and (4) imply that $C_{x}^{\prime}\left(x_{t}\right)+\tau_{t} \mu_{x}=C_{y}^{\prime}(y)+\tau_{t} \mu_{y}$, meaning that coal generation is used until its marginal costs are equalized with those of natural gas, inclusive of their respective emissions costs. The combination of these two equations means that, in the absence of an emissions price, an increase in renewables supply crowds out natural gas- and coal-fired generation in proportion to the slopes of their competing supply curves. A higher emissions price leads to a larger reduction in coal-fired production, since that is the only policy to differentiate between coal and gas.

\subsection{The nonemitting renewable energy sector}

Another sector of the industry generates without emissions by using renewable resources (wind, for example); it is denoted with superscript $\mathrm{R}$. Annual output from the renewables sector is $q_{t}$. The costs of production, $G\left(K_{t}, q_{t}\right)$, are assumed to be increasing and convex in output, and declining and convex in its own knowledge stock, $K_{t}$, so that $G_{q}>0, G_{q q}>0, G_{K}<0$, and $G_{K K}>0$, where lettered subscripts denote derivatives with respect to the subscripted variable. Furthermore, since marginal costs are declining in knowledge and the cross-partials are symmetric, $G_{q K}=G_{K q}<0$. Note that we have simplified considerably by assuming there is technological change in the relatively immature renewable energy technologies, but none in the relatively mature fossil-fueled technologies. While it is not strictly true that fossil-fueled technologies will experience no further advance, incorporation of positive but relatively slower innovation in fossil fuels would complicate the analysis without adding much additional insight. ${ }^{2}$

The knowledge stock $K\left(H_{t}, Q_{t}\right)$ is a function of cumulative knowledge from $\mathrm{R} \& \mathrm{D}, H_{t}$, and of cumulative experience through learning by doing, $Q_{t}$, where $K_{H} \geqslant 0$ and $K_{Q} \geqslant 0$, and $K_{Q H}=K_{H Q}$. Cumulative R\&D-based knowledge increases in proportion to annual R\&D knowledge generated in each stage, $h_{t}$, so $H_{2}=H_{1}+n_{1} h_{1}$. Cumulative experience increases with total output during the first stage, so $Q_{2}=Q_{1}+n_{1} q_{1}$. Research expenditures, $R\left(h_{t}\right)$, are increasing and convex in the amount of new R\&D knowledge generated in any one year, with $R_{h}(h)>0$ for $h>0, R_{h}(0)=0$, and $R_{h h}>0$. The strictly positive marginal costs imply that real resources - specialized scarce inputs, employees, and equipment - must be expended to gain any new knowledge. As a partial equilibrium model, we do not explicitly explore issues of crowding out in the general economy, but those opportunity costs may be reflected in the R\&D cost function. A subtle issue is whether research and experience are substitutes, in which case $K_{H Q} \leqslant 0$, or complements, making $K_{H Q}>0$.

Two price-based policies are directly targeted at renewable energy: a renewable energy production subsidy $(s)$ and a renewables technology R\&D subsidy in which the government offsets a share $(\sigma)$ of research

\footnotetext{
${ }^{2}$ An exception is advancement in cleaner fossil generation technologies like carbon capture and storage. Our qualitative results should carry over to policies targeting other low-carbon technologies, although the quantitative results would depend on the cost, technology, and emissions parameters particular to those other technologies.
} 
expenditures. In our two-stage model, profits for the representative nonemitting firm are thus

$$
\pi^{\mathrm{R}}=n_{1}\left(\left(P_{1}+s_{1}\right) q_{1}-G\left(K_{1}, q_{1}\right)-(1-\sigma) R\left(h_{1}\right)\right)+\delta n_{2}\left(\left(P_{2}+s_{2}\right) q_{2}-G\left(K_{2}, q_{2}\right)\right),
$$

where $K_{2}=K\left(H_{2}, Q_{2}\right)$.

Let $\rho$ be a factor reflecting the degree of appropriability of returns from investments in R\&D. ${ }^{3}$ In [12], this appropriation rate is formally derived for multiple innovating firms that derive their own benefits from knowledge and can to some degree appropriate the benefits that accrue to others as well. Aggregating to our representative firm, appropriated benefits can be represented as a share of the total. Thus, $\rho=1$ would reflect an extreme with perfect appropriability and no knowledge spillovers, while $\rho=0$ reflects the opposite extreme of no private appropriability of knowledge investments. Similarly, $1-\rho$ reflects the degree of knowledge spillovers. We assume that all knowledge is ultimately adopted, either by imitation or by licensing. Therefore, the spillover factor does not enter directly into the aggregate profit function, which reflects operating profits. Licensing revenues also do not appear because they represent transfers among firms. However, the spillover factor does enter into the first-order conditions for R\&D and learning, since it determines the share of future profit changes that can be appropriated by the representative innovator. These issues are further elaborated in [12].

Taking knowledge spillovers into account, the firm maximizes profits with respect to output in each stage and R\&D investment yielding the following first-order conditions:

$$
\begin{aligned}
& \frac{\partial \pi^{\mathrm{R}}}{\partial q_{1}}=n_{1}\left(P_{1}+s_{1}-G_{q}\left(K_{1}, q_{1}\right)\right)-\delta \rho n_{2} G_{K}\left(K_{2}, q_{2}\right) n_{1} K_{Q}\left(H_{2}, Q_{2}\right)=0, \\
& \frac{\partial \pi^{\mathrm{R}}}{\partial q_{2}}=\delta n_{2}\left(P_{2}+s_{2}-G_{q}\left(K_{2}, q_{2}\right)\right)=0 \text { and } \\
& \frac{\partial \pi^{\mathrm{R}}}{\partial h_{1}}=-n_{1}(1-\sigma) R_{h}\left(h_{1}\right)-\delta \rho n_{2} G_{K}\left(K_{2}, q_{2}\right) n_{1} K_{H}\left(H_{2}, Q_{2}\right)=0 .
\end{aligned}
$$

Rearranging, we get

$$
\begin{aligned}
& G_{q}\left(K_{1}, q_{1}\right)=P_{1}+s_{1}-\delta \rho n_{2} G_{K}\left(K_{2}, q_{2}\right) K_{Q}\left(H_{2}, Q_{2}\right), \\
& G_{q}\left(K_{2}, q_{2}\right)=P_{2}+s_{2} \text { and } \\
& R_{h}\left(h_{1}\right)=-\delta \frac{\rho}{(1-\sigma)} n_{2} G_{K}\left(K_{2}, q_{2}\right) K_{H}\left(H_{2}, Q_{2}\right) .
\end{aligned}
$$

As shown in Eq. (6), the renewable energy sector produces until the marginal cost of production equals the value it receives from additional output, including the market price, any production subsidy, and the appropriable contribution of such an output to future cost reduction through learning by doing (note that the last term in Eq. (6) is positive overall). Second-stage output does not generate a learning benefit, so there is no related term in Eq. (7). Meanwhile, as shown in Eq. (8), the firm also invests in research until the discounted appropriated returns from $\mathrm{R} \& \mathrm{D}$ equal investment costs on the margin.

Note that if appropriation rates are imperfect $(\rho<1)$, from a societal perspective, firms have insufficient incentive to engage in extra production for the purpose of learning by doing. Similarly, if the R\&D subsidy does not fully reflect the spillover values $(\sigma<1-\rho)$, firms have insufficient incentive to invest in R\&D. Thus, a knowledge externality accompanies the emissions externality, and both can be affected by policies that target one or the other.

\footnotetext{
${ }^{3}$ We model general knowledge as being appropriable, with no distinction regarding its source, be it R\&D or learning. While an empirical basis is lacking for such a distinction, one might expect some forms of learning to be less easily appropriated by other firms. For example, if learning is more firm-specific and less likely to spill over, policies subsidizing renewables are less appropriate to compensate for knowledge externalities. In contrast, if learning is more difficult to patent to appropriate rents, then renewable subsidies may be relatively more justified.
} 


\subsection{Consumer demand}

Renewable energy generation and fossil-fueled production are assumed to be perfect substitutes. We abstract from short-run peak pricing variations and take a longer-term view of demand and supply curves. Let $D(P)$ be the consumer demand for electricity, a function of the price, where $D^{\prime}(P)<0$. Consumer surplus is therefore $C S=\int_{P_{t}}^{\infty} D(P) d P$. Thus, the change in consumer surplus due to the renewable energy policy in this partial equilibrium model is

$$
\Delta \mathrm{CS}=-n_{1} \int_{P_{0}}^{P_{1}} D(P) d P-\delta n_{2}\left(\int_{P_{0}}^{P_{2}} D(P) d P\right) .
$$

In equilibrium, total consumption must equal total supply, the sum of fossil-fueled and renewable energy generation:

$$
D\left(P_{t}\right)=x_{t}+y_{t}+q_{t}
$$

In our application below, demand is the residual after exogenous supply of hydro and nuclear.

\subsection{Economic surplus}

Policies also have implications for government revenues, which we denote as $V$. We assume that these revenues are raised or returned in a lump-sum fashion. The change in these transfers equals the tax revenues net of the cost of the subsidies:

$$
\Delta V=n_{1}\left(\phi_{1} f_{1}+\tau_{1}\left(\mu_{x} x_{1}+\mu_{y} y_{1}\right)-s_{1} q_{1}-\sigma R\left(h_{1}\right)\right)+\delta n_{2}\left(\phi_{2} f_{2}+\tau_{2}\left(\mu_{x} x_{2}+\mu_{y} y_{2}\right)-s_{2} q_{2}\right) .
$$

Note that while we have assumed that the emissions price results in government revenue (either through a tax or auctioned permits), a permit system with free allocation would yield the same overall results in our model, with rents accruing to the permit holders rather than government. If, on the other hand, tax revenue changes were recycled by lowering more distortionary taxes in the economy, the revenue-raising policy options would perform relatively better. Incorporating such a feature would tend to widen the efficiency-cost gaps we find in our results.

Environmental benefits (i.e., reduced climate damages) are a function of the annual emissions and the length of each stage. To be able to accommodate both for flow and stock pollutants, we write this function in a general form:

$$
\Delta B=B\left(E_{1}, E_{2}, n_{1}, n_{2}\right)-B\left(E_{0}, E_{0}, n_{1}, n_{2}\right) .
$$

The change in economic surplus due to policy is the environmental benefits net of the sum of the changes in consumer/producer surplus and revenue transfers from subsidies/taxes:

$$
\Delta W=\Delta B+\Delta \mathrm{CS}+\Delta \pi+\Delta V
$$

where $\Delta \pi=\Delta \pi^{\mathrm{R}}+\Delta \pi^{\mathrm{F}}+\Delta \pi^{\mathrm{Other}}$, where $\Delta \pi^{\mathrm{F}}=\Delta \pi^{x}+\Delta \pi^{y}$. "Other" profits are revenue changes for other baseload generators, as we include nuclear and hydropower in our simulations; these generators have fixed costs and capacities and profit to the extent the electricity price rises.

However, economic surplus is unlikely to be the only metric for evaluating policy. Other indicators may be total emissions, consumer surplus, renewable energy market share, and so on. General equilibrium factorslike interactions with tax distortions, leakage [2], or other market failures - can also be important for determining welfare impacts. Allowing for distortionary taxes, for example, would likely widen the efficiency gap between revenue-raising and -using policies [14]. Political economy constraints may also be important for determining policy goals. To the extent that these unmodeled issues are present, this partial equilibrium presentation of economic surplus will not reflect the full social impacts; still, it is a useful metric. 


\subsection{Comparative statics}

It is useful to conduct comparative statics to consider the equilibrium effect of small changes in the different taxes and subsidies as shown in detail in [12]. With the exception of the R\&D subsidy, the impact of a policy change on the equilibrium price in each period has two components: (i) a direct effect in proportion to the policy change (tax or subsidy) and (ii) an indirect effect due to corresponding changes in knowledge accumulation and second-period renewable costs and output. The price of electricity is increasing in the fossilfueled output tax and the emissions tax and decreasing as renewable energy increases (which lowers necessary fossil-fueled supply). The R\&D subsidy, on the other hand, only induces an indirect effect on prices, through its impact on second-period renewable costs and the first-period benefits to learning. In all cases, the strength of these direct and indirect effects depends on the relative slopes of the supply and demand curves, which ultimately determine the overall price impact.

Both fossil-fueled generation sources decline as the fossil output tax increases and as renewable generation expands. The effect of the emissions tax on fossil generation is twofold: (i) a direct increase in costs that reduces generation in proportion to each source's emissions rate and (ii) an indirect effect that increases generation as a result of price increases due to cost increases in the other fossil source. The net effect can be positive or negative for natural gas, which emits $\mathrm{CO}_{2}$, but at about half the intensity of coal.

Second-period renewable output is increasing in all of the policy levers and in knowledge. We see similar effects in the first period, but the incidence of the policies is complicated by the endogeneity of knowledge accumulation and second-period production. First-period renewables output is increasing in the electricity price, the renewable subsidy, and in second-period renewable output due to learning investments. The effect of R\&D on first-period renewables output is more ambiguous: a positive $R \& D$ response will tend to temper the impact somewhat (due to diminishing returns to knowledge generation), but complementarity between learning and R\&D could possibly reinforce it.

We observe a similar ambiguity for R\&D: while $R \& D$ is increasing in the $R \& D$ subsidy and in secondperiod renewables output, it is ambiguously related to first-period renewables output, depending on whether R\&D and learning are substitutes or complements.

\subsection{Optimal policy}

In weighing different policy options, it is useful to bear in mind what the efficient policy combinations would be. In this situation, three policies are needed to optimally address three externalities: emissions, R\&D spillovers, and learning spillovers. An appropriate emissions price internalizes the first externality. To determine the optimal subsidies for R\&D and learning, we find what is necessary to align the private firstorder conditions with those of the social planner.

At the optimum, a coordinated research and learning program would yield

$$
\begin{aligned}
& \frac{\partial \pi^{\mathrm{R}}}{\partial q_{1}}=n_{1}\left(P_{1}-G_{q}\left(K_{1}, q_{1}\right)\right)-\delta n_{2} G_{K}\left(K_{2}, q_{2}\right) n_{1} K_{Q}\left(H_{2}, Q_{2}\right)=0, \\
& \frac{\partial \pi^{\mathrm{R}}}{\partial h_{1}}=-n_{1} R_{h}\left(h_{1}\right)-\delta n_{2} G_{K}\left(K_{2}, q_{2}\right) n_{1} K_{H}\left(H_{2}, Q_{2}\right)=0 .
\end{aligned}
$$

Thus, imperfect appropriability would not influence investment decisions. Rearranging, we get

$$
\begin{aligned}
& G_{q}\left(K_{1}, q_{1}\right)=P_{1}-\delta n_{2} G_{K}\left(K_{2}, q_{2}\right) K_{Q}\left(H_{2}, Q_{2}\right), \\
& R_{h}\left(h_{1}\right)=-\delta n_{2} G_{K}\left(K_{2}, q_{2}\right) K_{H}\left(H_{2}, Q_{2}\right) .
\end{aligned}
$$

Setting the right-hand sides of (16) and (6) to equal each other, as well as those of (17) and (8), we can solve for the optimal R\&D and learning subsidies when spillovers are present:

$$
\begin{aligned}
& \sigma=1-\rho, \\
& s_{1}=-(1-\rho) \delta n_{2} G_{K}\left(K_{2}, q_{2}\right) K_{Q}\left(H_{2}, Q_{2}\right) .
\end{aligned}
$$


In other words, an $R \& D$ subsidy is needed to offset the unappropriable share of $R \& D$ returns and a renewable generation subsidy is needed to offset the unappropriated gains from learning.

\section{Policy scenarios}

As developed in the modeling section, renewable energy production depends on the price received by that sector, the cost of R\&D investment, and the degree of appropriability of knowledge investments. Fossil-fueled energy production and the accompanying emissions depend on the amount of renewables sector output, the after-tax price of electricity, and the price of emissions. Consumer demand depends on the price of electricity. Different policies vary in their effects on these different prices resulting in different market equilibria.

\subsection{No policy}

We define $P_{t}^{0}$ as the baseline price of electricity generation, in the absence of policy (i.e., $\phi_{t}=s_{t}=\tau_{t}=\sigma=0$ ); the first-order conditions for production imply that output prices equal this baseline price in both markets and in each period: $P_{t}=P_{t}^{\mathrm{R}}$. We assume that an interior solution exists-that is, that some renewable energy is viable without any policy. A sufficient condition would be that $G_{q}\left(K_{1}, 0\right)<P_{1}^{0}$. However, renewable energy production could occur even if marginal production costs are higher than the price in the first stage, if there is sufficient value from learning by doing to lower second-stage costs. As a result, even without policy we would expect baseline prices to decline over time due to innovation.

\subsection{Fixed-price policies}

We look first at three policies that directly set prices: an emissions price, a renewables production subsidy, and a tax on fossil-based production. All three policies increase prices for renewables, which expands production and also induces more innovation. They differ in their effects on fossil energy production and emissions reduction.

Emissions price: With a direct price for emissions $\left(\tau_{t}\right)$-via either an emissions tax or a tradable emissions permit system - the fossil-fueled sector has an incentive to switch away from coal-fired generation. The market price of electricity increases in proportion to the weighted average emissions charge on fossil-fueled generation. Without other subsidies, the renewables sector receives the market price for electricity, and the price increase promotes greater renewable energy generation in both stages. The prospect of more output in the second stage increases knowledge investment incentives in the renewables sector, for both $\mathrm{R} \& \mathrm{D}$ and learning. The higher market price also means consumers have added incentive to conserve. The price increase does not fully compensate for the increase in the marginal costs of coal-fired generation (since $\tau_{t} \mu_{y}<\tau_{t} \mu_{x}$ ) resulting in less use of coal. Gas-fired generation may expand, however, if that option is more cost-effective than additional conservation or renewables on the margin.

In the absence of knowledge spillovers, the emissions price provides efficient incentives for achieving a given emissions reduction goal, as it provides equalized incentives for emissions reduction along all three marginsreduced emissions intensity, demand conservation (via price increase), and increased renewable output. With spillovers, however, a price reflecting the marginal damage from emissions would not offer efficient incentives for knowledge formation. The degree of inefficiency is an empirical matter, which we explore below.

Renewable power output subsidy: A renewables production subsidy $\left(s_{t}\right)$ boosts the price received by renewables and lowers its effective marginal cost relative to other sources. By putting downward pressure on the electricity price, the renewables subsidy crowds out fossil-fueled generation in both stages to reduce emissions. Because the market price of electricity declines, electricity use actually increases. Also, because there is no direct price on emissions, there is no discrimination between coal- and gas-fired generation to reduce emissions intensity.

Fossil power output tax: The analytic structure of a fossil-fueled production $\operatorname{tax}\left(\phi_{t}\right)$ is similar to the renewables subsidy because it raises the price received by renewables, except that it does so through higher consumer prices for electricity rather than a direct subsidy. Thus, both the market price and the effective price received by renewables rise in proportion to the tax. Although no incentive exists to reduce output or 
emissions specifically from coal relative to gas plants, to the extent that demand falls due to higher prices, fossil-fueled output and emissions will be lower than that under an equivalent renewable energy subsidy.

$R \& D$ subsidy for renewable energy technology: Without a price on emissions or tax/subsidy on output, output prices in both markets are affected only indirectly. The primary effect of the R\&D subsidy $(\sigma)$ is to increase research expenditures and lower future renewables costs, crowding out fossil-fueled generation in the second stage. The R\&D policy provides no incentive for energy conservation nor for reduction in coal relative to natural gas generation.

\subsection{Rate-based policies}

Two rate-based policies familiar to the electricity generation sector are portfolio standards and tradable performance standards. A portfolio standard requires a certain percentage of generation to come from renewable energy sources. A tradable performance standard-sometimes called a "generation performance standard" in the context of climate policies for the electricity sector-mandates that average emissions intensity per unit of output not exceed a standard. Both policies in effect create taxes on fossil-fueled generation and subsidies for renewable energy sources. However, those prices are not fixed, as in the previous policies, but rather adjust endogenously according to market conditions to achieve the targeted rate.

Endogenous prices raise additional issues with respect to innovation incentives. Essentially, as increased knowledge lowers renewable costs, a given standard becomes less costly to meet, which is then reflected in the implicit taxes and subsidies. The question is how the renewable sector perceives such price changes. Do firms in the sector recognize the impact of their innovation decisions on future prices? Do they myopically expect prices to remain unchanged? Or do they expect the future prices, taking them as given, as do competitive firms?

A long literature recognizes that innovation incentives differ, depending on the structure of markets for output and for innovation [3,13,26,27,31,40,44]. Given our assumption of a representative, perfectly competitive firm, we proceed by assuming that renewable energy firms have perfect foresight about price changes and take them as given. That is, each firm expects knowledge to accumulate and permit prices to respond to that accumulation, but no individual firm expects to influence future prices by its own $R \& D$ or learning. In recognizing the equilibration of future prices, $R \& D$ incentives are diminished relatively if expectations were myopic. If firms expect their own actions to further reduce those prices, the expected returns to knowledge would also fall. This contrasts with [13], where innovators are permit buyers not sellers. In our numerical simulations, we assume that the rate-based targets are adjusted so that the equilibrium price premium to renewables remains constant over time.

Renewable energy portfolio standard: We model the portfolio standard as a requirement that a specific percentage of generation be from renewable energy sources in each stage. We assume that responsibility lies with the emitting industry to satisfy the portfolio constraint. Thus, the fossil-fueled producer must purchase or otherwise ensure a share of at least $\alpha_{t}$ units of renewable energy for every $\left(1-\alpha_{t}\right)$ units of fossil-fueled generation or $\alpha_{t} /\left(1-\alpha_{t}\right)$ green certificates for every unit generated. Furthermore, we allow the standard to tighten over time, to allow easier comparison with the price mechanisms and to better reflect actual policy proposals.

In equilibrium, the incentives correspond to a combination of a tax on fossil generation and a subsidy on renewables. Assuming the renewable market share constraint binds, renewables receive a subsidy per unit output equal to the price of a green certificate, $\hat{s}_{t}$, where "^" denotes equilibrium values under the portfolio standard. The effective tax per unit of fossil-fueled output under this policy, $\hat{\phi}_{t}$, is then proportional to the effective subsidy to renewables:

$$
\hat{\phi}_{t}=\frac{\alpha_{t}}{1-\alpha_{t}} \hat{s}_{t}
$$

The implicit tax and subsidy and electricity price are determined competitively by the market to meet the portfolio constraint.

The portfolio standard provides no incentive to reduce coal reliance relative to gas, but crowds out fossilfueled generation by implicitly taxing it and subsidizing renewables compared to the market price. Since it combines a fossil energy tax (which raises electricity prices) with a renewables subsidy (which lowers electricity 
prices), the portfolio standard has an ambiguous effect on consumer prices resulting in limited energy conservation incentives, if any [11].

Another important difference is that, for a given portfolio standard, the implicit tax and subsidy decline with reductions in renewable energy costs. This occurs because the implicit tax/subsidies reflect the shadow cost of meeting the renewables production constraint, and this shadow cost declines as the cost of renewables production declines. As a result, to maintain constant policy prices over time, the portfolio standard must become more stringent.

Emissions performance standard: While a portfolio standard requires a certain percentage of renewable energy, a performance standard requires a maximum average emissions intensity of fossil and renewable generation combined. With a tradable performance standard of $\bar{\mu}_{t}$, the emitting firm must buy emissions permits to the extent that its emissions rate exceeds that standard. The price of emissions at time $t, \tilde{\tau}_{t}$, will now be determined by a market equilibrium, denoted by " $"$ ". All firms are in effect allocated $\bar{\mu}_{t}$ permits per unit of output, which leads to an implicit subsidy of $\tilde{\tau}_{t} \bar{\mu}_{t}$ per unit of output. Thus, if the standard is binding, the fossilfueled sector will be a net buyer of permits costing $\tilde{\tau}_{t}\left(\mu_{x}-\bar{\mu}_{t}\right)$ per unit of output for coal generation and $\tilde{\tau}_{t}\left(\mu_{y}-\bar{\mu}_{t}\right)$ for natural gas generation. (Note, however, that if the emissions intensity of gas is less than the standard $\mu_{y}<\bar{\mu}_{t}$, gas generation becomes a net seller of permits.) The renewables sector will be a seller of permits valued at $\tilde{\tau}_{t} \bar{\mu}_{t}$ per unit of output.

Thus, the emissions performance standard corresponds to a combination of an emissions price $\left(\tilde{\tau}_{t}\right)$, and a generation subsidy for both renewable $\left(\tilde{s}_{t}\right)$ and fossil producers $\left(-\tilde{\phi}_{t}\right)$, where

$$
\tilde{s}_{t}=\tilde{\tau}_{t} \bar{\mu}_{t}=-\tilde{\phi}_{t} .
$$

The equilibrium values are determined in conjunction with the previous market-clearing conditions for energy supply and demand, along with the additional emissions constraint that

$$
\mu_{x} x_{t}+\mu_{y} y_{t} \leqslant \bar{\mu}_{t}\left(q_{t}+f_{t}\right) \text {. }
$$

The impact of the emissions performance standard on electricity prices could be positive or negative, depending on whether the effect of the implicit tax on emissions dominates the effect of the implicit subsidy. The relative effects depend largely on the slopes of the marginal cost curves. Because of the implicit output subsidy, conservation incentives (if any) are limited. As a result, emissions are higher compared to an equivalent pure emissions price (i.e., if $\tau_{t}=\tilde{\tau}_{t}$ ).

Like the portfolio standard, a fixed performance standard implies a subsidy that changes as renewable costs fall. Further, an expansion of renewables allows fossil generation emissions to increase-partly from greater production and partly from increased emissions intensity as the permit price falls. To maintain prices for renewables, the standard must therefore be tightened.

\subsection{Summary comparison of policies}

With regard to cost-effective emissions reduction, the relative performance of the policies differs according to the incentives they provide for reducing emissions intensity, reducing energy consumption, increasing renewable energy production, and decreasing costs through innovation (a related distinction is made in [16]). Table 1 summarizes the incentive effects from each of these policies along these different dimensions. As one moves from the left of Table 1 to the right, therefore, efficiency tends to decrease, although the precise ranking of instruments depends on the relative strength of the different incentives in particular empirical circumstances.

The revenue and distributional implications of the policies are also quite different. The fossil-based output tax raises revenue, as does the emissions price if it is implemented through auctioned permits or emissions taxes. Price increases are borne by producers and consumers in relation to supply and demand elasticities. The renewables subsidy and $R \& D$ subsidy require outlays of public funds; taxpayers support the renewable energy producers, while electricity consumers and fossil producers are held harmless. The standards involve no net revenue change, implicitly earmarking the net costs of these policies back to consumers and producers. The net effects on economic surplus depend on the magnitude of the efficiency loss in the process.

Since no one policy perfectly addresses all market failures - the emissions externality and knowledge spillovers from both R\&D and learning - a clear ranking cannot be derived analytically. Each policy applies 
Table 1

Incentives from alternative policies

\begin{tabular}{|c|c|c|c|c|c|c|}
\hline & Emissions price & $\begin{array}{l}\text { Tradable } \\
\text { emissions } \\
\text { perform. std. }\end{array}$ & $\begin{array}{l}\text { Output tax on } \\
\text { fossil } \\
\text { generation }\end{array}$ & $\begin{array}{l}\text { Renewables } \\
\text { portfolio } \\
\text { standard }\end{array}$ & $\begin{array}{l}\text { Renewables } \\
\text { production } \\
\text { subsidy }\end{array}$ & $\begin{array}{l}\text { Renewables } \\
\text { research } \\
\text { subsidy }\end{array}$ \\
\hline $\begin{array}{l}\text { Reduce emissions } \\
\text { intensity of fossil fuels }\end{array}$ & Yes & Yes & No & No & No & No \\
\hline $\begin{array}{l}\text { Energy conservation (via } \\
\text { electricity price increase) }\end{array}$ & Yes & It depends & Yes & It depends & No & No \\
\hline $\begin{array}{l}\text { Direct subsidy for } \\
\text { renewable energy output }\end{array}$ & No & Yes (implicit) & No & Yes (implicit) & Yes & No \\
\hline Direct subsidy for $\mathrm{R} \& \mathrm{D}$ & No & No & No & No & No & Yes \\
\hline
\end{tabular}

Table 2

Parameter values and other assumptions

\begin{tabular}{|c|c|}
\hline Parameter & Base value \\
\hline Baseline price of electricity $(\$ / \mathrm{kWh})$ & 0.073 \\
\hline Intercept of coal-based electricity supply $\left(c_{y 1}\right)(\$ / \mathrm{kW} \mathrm{h})$ & 0.023 \\
\hline Slope of coal-based electricity supply $\left(c_{y 2}\right)\left(\$ / \mathrm{kW} \mathrm{h}^{2}\right)$ & $2.2 \times 10^{-14}$ \\
\hline Intercept of natural gas electricity supply $\left(c_{x 1}\right)(\$ / \mathrm{kWh})$ & 0.061 \\
\hline Slope of natural gas electricity supply $\left(c_{x 2}\right)\left(\$ / \mathrm{kW} \mathrm{h}^{2}\right)$ & $1.8 \times 10^{-14}$ \\
\hline Intercept of renewables electricity supply $\left(g_{1}\right)(\$ / \mathrm{kWh})$ & 0.059 \\
\hline Slope of renewables electricity supply $\left(g_{2}\right)\left(\$ / \mathrm{kW} \mathrm{h}^{2}\right)$ & $1.2 \times 10^{-13}$ \\
\hline $\mathrm{CO}_{2}$ intensity of coal-based electricity $\left(\mu_{x}\right)\left(\mathrm{kg} \mathrm{CO}_{2} / \mathrm{kW} \mathrm{h}\right)$ & 0.96 \\
\hline $\mathrm{CO}_{2}$ intensity of natural gas-based electricity $\left(\mu_{y}\right)\left(\mathrm{kg} \mathrm{CO}_{2} / \mathrm{kW} \mathrm{h}\right)$ & 0.42 \\
\hline Electricity demand elasticity $(\varepsilon)$ & -0.20 \\
\hline Learning parameter $\left(k_{1}\right)$ & 0.15 \\
\hline $\mathrm{R} \& \mathrm{D}$ parameter $\left(k_{2}\right)$ & 0.15 \\
\hline $\mathrm{R} \& \mathrm{D}$ investment cost parameter $\left(\gamma_{0}\right)$ & $3.9 \times 10^{9}$ \\
\hline $\mathrm{R} \& \mathrm{D}$ investment cost parameter $\left(\gamma_{1}\right)$ & 1.2 \\
\hline Degree of appropriability $(\rho)$ & 0.50 \\
\hline
\end{tabular}

a different set of levers, for which the relative effectiveness depends on parameter values. For example, a tradable performance standard can reduce the emissions intensity of fossil-fueled generation, and subsidize renewable energy, but it discourages conservation. Therefore, it may or may not outperform a fossil tax or renewable subsidy alone. Thus, we turn to a numerical application to explore both the magnitude of the efficiency-cost differences and their sensitivity to specific parameter assumptions.

\section{Numerical application to U.S. electricity production}

In this section we apply the theory developed above to a stylized representation of the U.S. electricity production sector. We begin by specifying functional forms that have the general properties given above, that correspond to available information in the form of particular relationships, and that are empirically tractable. We also describe the empirical derivation of values for necessary parameters and base levels of variables using available information. Table 2 summarizes the parameter values used in the numerical application. We then describe the results of our central scenario, as well as sensitivity analyses for key relationships.

\subsection{Functional form and parametric assumptions}

We specify quadratic cost functions for coal-based and natural gas-based electricity generation: $C_{x}\left(x_{t}\right)=$ $c_{x 0}+c_{x 1} x_{t}+c_{x 2} x_{t}^{2} / 2$ and $C_{y}\left(y_{t}\right)=c_{y 0}+c_{y 1} y_{t}+c_{y 2} y_{t}^{2} / 2$, thereby yielding linear electricity supply curves, 
$C_{x}^{\prime}\left(x_{t}\right)=c_{x 1}+c_{x 2} x_{t}$ and $C_{y}^{\prime}\left(y_{t}\right)=c_{y 1}+c_{y 2} y_{t}$. We also assume that the renewable generation cost function is quadratic, $G_{t}\left(K_{t}, q_{t}\right)=K_{t}^{-1}\left(g_{1} q_{t}+g_{2} q_{t}^{2} / 2\right)$, yielding a linear renewables supply curve, $G_{q}\left(K_{t}, q_{t}\right)=$ $K_{t}^{-1}\left(g_{1}+g_{2} q_{t}\right)$. Total and marginal costs of renewables generation are proportional to the inverse of the knowledge stock, so that technological change lowers both the intercept and slope of the renewables supply curve.

We calibrate the values of $c_{x 1}, c_{x 2}, c_{y 1}$, and $c_{y 2}$ to a recent set of simulations of the electricity market impacts of alternative $\mathrm{CO}_{2}$ reduction goals from the Energy Information Administration's (EIA) National Energy Modeling System (NEMS) [10] which, with along other studies, supports the assumption of approximately linear marginal abatement costs over the policy range we explore. The $\mathrm{CO}_{2}$ intensities of coal-based and natural-gas-based electricity are set to $\mu_{x}=0.96$ and $\mu_{y}=0.42 \mathrm{~kg}$ of $\mathrm{CO}_{2}$ per $\mathrm{kWh}(\mathrm{kg} \mathrm{CO} / \mathrm{kWh})$, respectively, based on the same EIA study [10]. These emissions intensities are not projected to change measurably under the climate policies modeled. The baseline price of electricity is $7.3 \mathrm{cent} / \mathrm{kWh}$ based on projected future values of the average price of electricity [10]. See Table 2 for parameter values and other assumptions; all monetary values are adjusted to year 2004 values.

To set a value for the slope of the renewable supply function $\left(g_{2}\right)$, we rely on recent studies of proposed national renewable portfolio standards [8,38], which suggest that a $10 \%$ renewable share would lead to a renewable credit price of about $0.03 \$ / \mathrm{kWh}$. This implies a slope of the renewable supply function of $g_{2}=1.2 \times 10^{-13} \$ / \mathrm{kW} \mathrm{h}^{2}$. We solve for the intercept of the renewable supply function so that the numerical model yields baseline annual renewable generation of $1.4 \times 10^{11} \mathrm{~kW} \mathrm{~h}$ (EIA projection for 2010 [10]) yielding $g_{1}=0.060 \$ / \mathrm{kWh}$.

We specify a knowledge stock having a constant elasticity relationship with respect to both the stock of experience and the stock of $\mathrm{R} \& \mathrm{D}, K_{t}\left(Q_{t}, H_{t}\right)=\left(Q_{t} / Q_{1}\right)^{k_{1}}\left(H_{t} / H_{1}\right)^{k_{2}}$, implying that $K_{1}=1$. We normalize the first-period R\&D knowledge stock so that $H_{1}=1$. This functional form has commonly been used for this relationship, and it is empirically supported by studies of the relationship between learning by doing and product costs and the relationship between productivity and $R \& D$. This functional form implies complementarity between R\&D and learning, which is supported by the limited empirical evidence available [29]. We set $Q_{1}=1.4 \times 10^{12} \mathrm{kWh}$ so that annual renewable energy generation represents about a $10 \%$ contribution to the stock of experience, which is consistent with the current U.S. contribution of wind, solar, and biomass generation to cumulative U.S. output of these energy sources [7].

We set the values for $k_{1}$ and $k_{2}$ in our central scenario based on several pieces of evidence. Different approaches to the empirical study of technological change suggest that it is reasonable to set benchmark values of $k_{1}=0.15$ and $k_{2}=0.15$ with their sum at about 0.3 . Numerous empirical "learning curve" studies estimate the elasticity of product costs (or prices) with respect to cumulative production. These studies find a peak in the distribution of estimated elasticities at about 0.30 [1]. Specifically with regard to renewable energy, the International Energy Agency [19] suggests that the learning rate for electricity from wind has also been about 0.30 .

One of the reasons for the pervasive relationship between cumulative production and product cost declines is likely to be the common decision rule in many firms of allocating a given percentage of revenues to $R \& D$. As R\&D is typically not explicitly included in learning curve analyses, the effect of output-proportionate R\&D investments will tend to be reflected in the estimated learning elasticity. Thus, it is appropriate to view many estimated learning rates as closer to the sum of $k_{1}$ and $k_{2}$ rather than $k_{1}$ alone. The NEMS, for example, assumes a maximum learning rate of 0.10 for renewable energy technologies within its electricity market module [9] but also includes other sources of technological change.

A distinct line of research has investigated the relationship of production and cost functions and the stock of R\&D knowledge, typically based on a constructed stock of R\&D capital. The elasticity of R\&D in these studies tends to be around 0.08-0.30 [33], again suggesting that a value of $k_{2}=0.15$ is reasonable. Porter and Stern [43] use a patent-based measure of the knowledge stock, finding that a doubling of the patent stock leads to about a $10 \%$ increase in total factor productivity. This is also consistent with an elasticity of $k_{2}=0.15$. Our assumptions regarding the values of $k_{1}$ and $k_{2}$ are also supported by empirical evidence from Klaassen et al. [28] on learning in electricity production from wind.

In our sensitivity analysis, we explore different relative contributions of learning and R\&D to knowledge, while holding constant the rate of technological change (i.e., decline in renewable energy costs) achieved in the 
central case. This reflects our sense that while there is an empirically observable overall rate of technological change, it is very difficult in practice to distinguish its underlying sources, be it learning or R\&D. The level of cost reduction turns out to be $12 \%$ over the $5 \mathrm{yr}$ from the first to second stage of the model, which is reasonable given recent historical and projected future cost declines for renewable energy.

A constant elasticity R\&D investment function, $R\left(h_{1}\right)=\gamma_{0} h_{1}^{\gamma_{1}}$, has the desired properties set out above so long as $\gamma_{1}>1$. We set $\gamma_{1}=1.2$ based on a number of firm-level empirical studies of the relationship between knowledge generation, as measured by patenting, and R\&D investments. ${ }^{4}$ Second, we assume that annual baseline R\&D spending is 3\% of revenues or $\$ 300$ million, which corresponds to the average R\&D intensity of U.S. industry [35] and is consistent with limited information available on private U.S. renewables R\&D spending [34]. Calibrating the model to all other baseline assumptions yields $\gamma_{0}=3.9 \times 10^{9}$ for the central scenario.

Drawing from a sizable empirical literature estimating the private and social returns to knowledge (e.g., $[18,25,33])$, we set $\rho=0.50$, which is consistent with a social return to knowledge (i.e., including spillovers) that is roughly twice the private return. ${ }^{5} \mathrm{We}$ explore a range of appropriability factors from 0.25 to 1.0 in sensitivity analysis.

We assume a constant elasticity of aggregate electricity demand with respect to the price of electricity, $\varepsilon$, so that $D_{t}=D\left(P_{0}\right)+\left(P_{t}-P_{0}\right) d D / d P$, where $d D / d P=\varepsilon D\left(P_{0}\right) / P_{0}$. We assume $\varepsilon=-0.20$ based on the implied elasticity from the EIA-NEMS climate policy study discussed above. We set baseline energy demand at $4.20 \times 10^{12} \mathrm{~kW}$ h in 2010 based on projected coal-based generation of $2.29 \times 10^{12} \mathrm{~kW}$ h, natural gas generation of $0.67 \times 10^{12} \mathrm{kWh}$, renewable generation of $0.14 \times 10^{12} \mathrm{kWh}$, and nuclear and hydro generation of $1.10 \times 10^{12} \mathrm{~kW} \mathrm{~h} \mathrm{[10].} \mathrm{We} \mathrm{hold} \mathrm{nuclear} \mathrm{and} \mathrm{hydro} \mathrm{constant} \mathrm{in} \mathrm{the} \mathrm{simulation} \mathrm{as} \mathrm{these} \mathrm{generation} \mathrm{sources} \mathrm{are}$ not expected to change in response to the policies we evaluate [10]. We consider a first stage of length $n_{1}=5 \mathrm{yr}$, which is typical of the time required for new innovations to be brought to market [36]. We discount the second stage back to the present at a private real rate of return of $10 \%$ (so that $\delta=0.62$ ), and consider a second stage $20 \mathrm{yr}$ long, whose flows we discount to the start of the second stage at $10 \%$ (so that $n_{2}=8.5$ ). Twenty years is a typical cost recovery period for analysis of electricity generation technologies [9].

\subsection{Policy simulation approach}

The baseline outcomes of this model in the absence of policy are given in Table 3. We begin the policy simulations by computing the effects of an emissions price of $\$ 7 /$ ton $\mathrm{CO}_{2}$ in place throughout the model horizon (or about $\$ 25$ per ton of carbon). For the alternatives, we compute the level of the policy necessary to achieve the same total level of emissions as the emissions price. We hold total emissions constant across the alternative policies to hold environmental benefits constant so that we can consider differences in economic surplus across policies as arising solely from differences in consumer surplus, producer surplus, and transfers related to electricity consumption and production. This approach is reasonable so long as the marginal benefits of emissions reduction are fairly constant in the level of reductions and over the relevant time horizon, which is a reasonable assumption for $\mathrm{CO}_{2}$ emissions [37].

For the two rate-based policies (portfolio standard and emissions performance standard), we set the rates so that the price of credits is the same in the two periods while meeting the emissions target. This results in an increasing stringency of the rate-based policies over time (see Table 4). The resulting renewable portfolio standard rises from $6.0 \%$ in the first period to $9.6 \%$ in the second period, which is close to a recent policy proposal for a national renewable portfolio standard rising from $5 \%$ by 2012 to $10 \%$ by 2020 [8]. As the model does not permit an analytical solution, we numerically solve the nonlinear system of equations using Newton's method.

\footnotetext{
${ }^{4}$ Griliches [17] suggests that for larger firms the degree of diminishing returns is only slight. Jaffe [22] finds an elasticity of patents with respect to R\&D of over 0.8 in his preferred specification with other related studies finding similar results [4]. Our model uses the inverse of this elasticity, with the knowledge production to R\&D elasticity being $\frac{1}{1.2}=0.83$.

${ }^{5}$ The parameter values governing technological change in our central numerical scenario are based on empirical evidence generated in the presence of existing R\&D policy. The measured private versus social rates of return to R\&D, spillovers, and appropriability rates therefore incorporate preexisting corrective policies. Since social returns remain above private returns, we find a positive optimal R\&D subsidy in addition to preexisting policy.
} 
Table 3

Baseline results without policy

\begin{tabular}{|c|c|c|}
\hline & First stage & Second stage \\
\hline Price of electricity $(\$ / \mathrm{kWh})$ & 0.073 & 0.072 \\
\hline Electricity demand $(\mathrm{kW} \mathrm{h} / \mathrm{yr})$ & $4.20 \times 10^{12}$ & $4.20 \times 10^{12}$ \\
\hline Coal generation $(\mathrm{kW} \mathrm{h} / \mathrm{yr})$ & $2.29 \times 10^{12}$ & $2.27 \times 10^{12}$ \\
\hline Natural gas generation $(\mathrm{kWh} / \mathrm{yr})$ & $0.67 \times 10^{12}$ & $0.64 \times 10^{12}$ \\
\hline Renewables generation $(\mathrm{kWh} / \mathrm{yr})$ & $0.14 \times 10^{12}$ & $0.20 \times 10^{12}$ \\
\hline Nuclear and hydro generation $(\mathrm{kW} \mathrm{h/yr)}$ & $1.10 \times 10^{12}$ & $1.10 \times 10^{12}$ \\
\hline Renewables share of generation $(\%)$ & 3.3 & 4.8 \\
\hline $\mathrm{CO}_{2}$ emissions (billion metric tons $\mathrm{CO}_{2} / \mathrm{yr}$ ) & 2.48 & 2.44 \\
\hline Rate of renewables cost reduction $(\%)$ & 12 & - \\
\hline
\end{tabular}

Table 4

Annual effects of alternative policies relative to base case

\begin{tabular}{|c|c|c|c|c|c|c|}
\hline & $\begin{array}{l}\text { Emissions } \\
\text { price } \\
\left(\$ / \text { ton } \mathrm{CO}_{2}\right)\end{array}$ & $\begin{array}{l}\text { Tradable } \\
\text { emissions } \\
\text { perform. std. } \\
\text { (ton } \mathrm{CO}_{2} / \mathrm{GW} \mathrm{h} \text { ) }\end{array}$ & $\begin{array}{l}\text { Output tax on } \\
\text { fossil } \\
\text { generation } \\
\text { (cent } / \mathrm{kWh} \text { ) }\end{array}$ & $\begin{array}{l}\text { Renewables } \\
\text { portfolio } \\
\text { standard }\end{array}$ & $\begin{array}{l}\text { Renewables } \\
\text { production } \\
\text { subsidy } \\
\text { (cent } / \mathrm{kWh} \text { ) }\end{array}$ & $\begin{array}{l}\text { Renewables } \\
\text { research } \\
\text { subsidy }\end{array}$ \\
\hline $\begin{array}{l}\text { Policy for } 4.8 \% \\
\text { abatement }\end{array}$ & 7.0 & $765 / 743$ & 0.83 & $6.0 \% / 9.6 \%$ & 1.4 & $88 \%$ \\
\hline \multicolumn{7}{|l|}{ Electricity price } \\
\hline First stage (\%) & 5.3 & -1.9 & 9.4 & -0.4 & -1.5 & -0.2 \\
\hline Second stage $(\%)$ & 5.0 & -2.2 & 8.8 & -0.9 & -2.7 & -3.0 \\
\hline \multicolumn{7}{|l|}{$\mathrm{CO}_{2}$ emissions } \\
\hline First stage $(\%)$ & -4.2 & -3.9 & -3.7 & -2.9 & -2.9 & -0.4 \\
\hline Second stage $(\%)$ & -5.0 & -5.1 & -5.1 & -5.3 & -5.3 & -5.9 \\
\hline \multicolumn{7}{|l|}{ Renewable generation } \\
\hline First stage $(\%)$ & 26 & 40 & 46 & 80 & 86 & 11 \\
\hline Second stage $(\%)$ & 33 & 50 & 58 & 101 & 109 & 122 \\
\hline \multicolumn{7}{|l|}{$\begin{array}{l}\text { Coal generation and } \\
\text { emissions }\end{array}$} \\
\hline First stage $(\%)$ & -5.7 & -6.4 & -2.7 & -2.1 & -2.1 & -0.3 \\
\hline Second stage $(\%)$ & -6.3 & -7.3 & -3.7 & -3.9 & -3.9 & -4.3 \\
\hline \multicolumn{7}{|l|}{$\begin{array}{l}\text { Gas generation and } \\
\text { emissions }\end{array}$} \\
\hline First stage $(\%)$ & 7.6 & 15.8 & -11.5 & -9.0 & -8.9 & -1.1 \\
\hline Second stage $(\%)$ & 5.6 & 13.0 & -16.1 & -16.8 & -16.8 & -18.8 \\
\hline \multicolumn{7}{|l|}{$\begin{array}{l}\text { Total electricity } \\
\text { generation }\end{array}$} \\
\hline First stage $(\%)$ & -1.0 & 0.4 & -1.8 & 0.1 & 0.3 & 0.0 \\
\hline Second stage $(\%)$ & -1.0 & 0.4 & -1.7 & 0.2 & 0.5 & 0.6 \\
\hline $\begin{array}{l}\text { Renewable R\&D } \\
\text { increase }(\%)\end{array}$ & 75 & 118 & 139 & 255 & 277 & 4043 \\
\hline $\begin{array}{l}\text { Additional renewables } \\
\text { cost reduction }(\%)\end{array}$ & 4 & 5 & 6 & 10 & 11 & 25 \\
\hline $\begin{array}{l}\Delta \text { Consumer surplus } \\
(\mathrm{SB} / \mathrm{yr})\end{array}$ & -15.5 & 6.2 & -27.6 & 2.1 & 6.4 & 5.0 \\
\hline $\begin{array}{l}\Delta \text { Producer surplus } \\
(\$ B / y r)\end{array}$ & -1.1 & -6.5 & 4.4 & -2.6 & -2.2 & -2.5 \\
\hline$\Delta$ Transfers $(\$ B / y r)$ & 16.4 & 0.0 & 22.8 & 0.0 & -4.8 & -5.5 \\
\hline $\begin{array}{l}\Delta \text { Surplus (excluding } \\
\text { environ. benefits) } \\
(\$ B / y r)\end{array}$ & -0.24 & -0.33 & -0.38 & -0.48 & -0.58 & -2.9 \\
\hline $\begin{array}{l}\Delta \text { Surplus relative to } \\
\text { emissions price }\end{array}$ & 1.00 & 1.41 & 1.61 & 2.04 & 2.47 & 12.49 \\
\hline
\end{tabular}




\subsection{Central scenario}

In reviewing the results of the central scenario (see Tables 4 and 5), perhaps the first point to note is that the emissions price is indeed the most efficient means of achieving a given emissions target, leading to the least cost in terms of surplus, and also requiring the least investment in renewable energy R\&D. A \$7/ton $\mathrm{CO}_{2}$ emissions price reduces electricity emissions by $4.8 \%$ in our central scenario. In the first stage, the $\mathrm{CO}_{2}$ price reduces coal emissions by $5.7 \%$, encourages switching to natural gas generation (which increases by $7.6 \%$ ), reduces electricity consumption by $1.0 \%$ due to a $5.3 \%$ rise in the price of electricity, and increases renewable generation by $23 \%$, the lowest renewable increase of any of the policies. Correspondingly, less renewables $\mathrm{R} \& \mathrm{D}$ investment is necessary than that under the other policies, with $\mathrm{R} \& \mathrm{D}$ rising by $75 \%$ over the baseline. As indicated by the change in consumer surplus, however, the burden on consumers may be large if they do not benefit from revenue transfers.

The implicit output subsidy inherent in the tradable performance standard leads to lesser reductions coming from consumption (which actually increases slightly due to a fall in electricity prices). Consequently, more reductions must come from displacing coal and expanding renewables. The implicit emissions price inherent in the tradable performance standard is $\$ 9.5 /$ ton $\mathrm{CO}_{2}$ or $36 \%$ higher than that under the explicit emissions price policy. In the first stage, natural gas and renewables are brought in to replace coal; as renewables production increases in the second stage it displaces part of this gas increase. For the renewables sector, the combination of the implicit emissions price and renewable subsidy implies a $0.6 \mathrm{cent} / \mathrm{kW} \mathrm{h}$ increase in the price received by renewables, $0.2 \mathrm{cent} / \mathrm{kWh}$ higher than that under the direct emissions price, inducing moderate expansions over that scenario. Overall, the net economic costs are $41 \%$ higher than the emissions price, making the emissions performance standard the second-most cost-effective instrument. Since the standard is such that the price of electricity falls (because the emissions intensity of gas is less than the standard), consumers directly benefit in this scenario, while baseload producers lose revenues; coal is hit hardest, due to the higher emissions price.

The output tax of $0.8 \mathrm{cent} / \mathrm{kWh}$, since it does not tax emissions directly, places more of the reduction burden on reducing consumption, displacing gas, and increasing renewables. This increases the overall cost of the policy by $61 \%$ relative to the emissions price. By raising electricity prices by about $75 \%$ more than the emissions price, the output tax results in a price increase for renewables of 0.7 cent $/ \mathrm{kW} \mathrm{h}$, about $75 \%$ more than with the emissions price, resulting in comparable increases in renewables output and R\&D investment. The fossil output tax also almost doubles the costs to consumers, while government revenues are significantly higher than that under the emissions price. Profits to producers using nuclear and hydropower increase substantially, more than offsetting profit losses of producers using coal and gas.

A renewables portfolio standard implicitly combines a nearly 0.1 cent $/ \mathrm{kW} \mathrm{h}$ fossil output tax with a 1.2 cent $/ \mathrm{kW} \mathrm{h}$ renewables production subsidy. With no conservation incentives (electricity prices actually decrease by a small amount) and no fossil fuel-switching incentives, renewables must expand three times as much as with the emissions price to meet the target. As a result, its performance is 2.04 times as costly as the emissions price in

Table 5

Explicit and implicit taxes and subsidies of alternative policies

\begin{tabular}{|c|c|c|c|c|}
\hline \multirow[t]{2}{*}{ Policy } & \multicolumn{3}{|c|}{ Explicit and implicit taxes and subsidies } & \multirow{2}{*}{ 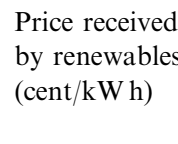 } \\
\hline & $\begin{array}{l}\text { Emissions price } \\
\left(\$ / \text { ton } \mathrm{CO}_{2}\right)\end{array}$ & $\begin{array}{l}\text { Output tax on fossil } \\
\text { generation }(\text { cent } / \mathrm{kWh} \text { ) }\end{array}$ & $\begin{array}{l}\text { Renewables subsidy } \\
\text { (cent/kW h) }\end{array}$ & \\
\hline \multicolumn{5}{|l|}{ Fixed-price policies } \\
\hline Emissions price & 7.0 & - & - & 7.7 \\
\hline Output tax on fossil generation & - & 0.8 & - & 8.0 \\
\hline Renewables production subsidy & - & - & 1.4 & 8.6 \\
\hline \multicolumn{5}{|l|}{ Rate-based policies } \\
\hline Emissions performance standard & 9.5 & -0.7 & 0.7 & 7.9 \\
\hline Renewables portfolio standard & - & 0.1 & 1.2 & 8.5 \\
\hline
\end{tabular}


our central scenario. Since no revenues are raised and electricity prices fall slightly, producers (in aggregate) bear the policy burden. Renewable electricity producers gain while other producers lose. Consumers also gain from the price fall, which occurs when the implicit production subsidy outweighs the implicit tax on nonrenewable generation. However, the incidence of these implicit taxes depends on the relative slopes of the fossil-fueled and renewable supply. For example, the electricity price would not fall if the marginal cost of gasfired generation were sufficiently flat [11].

The renewables production subsidy of $1.4 \mathrm{cent} / \mathrm{kW} \mathrm{h}$, to generate the same emissions reductions, must be nearly twice the fossil output tax, since electricity consumption is increased, rather than reduced, due to a decrease in prices. The effects are similar to the portfolio standard, though somewhat larger, since renewables must also accommodate the increased electricity consumption. Consumers face lower electricity costs and renewable electricity gains, but this is more than offset by the cost to taxpayers and nonrenewable electricity producers. The overall cost of the policy in achieving emissions reductions is 2.47 times that of the emissions price.

Finally, it may be of little surprise that the renewables research subsidy is by far the most costly single policy for reducing emissions, since virtually all the burden of displacing fossil output falls in the second stage. Costeffective early emissions reductions are forgone, and all emissions reductions must be gained in the second stage by making renewables less expensive than fossil fuels in the absence of any emissions or conservation incentive. To do so without any output or emissions incentive requires costs to fall six times as much as with the emissions tax or $25 \%$ overall. While second-stage renewable output expands by $122 \%$, it also expands in the first stage relative to the emissions price, a result of the complementarity of learning with R\&D.

\subsection{Sensitivity analyses}

We conduct several sensitivity analyses. The results are given in Table 6, where for brevity we focus on the economic surplus of each policy relative to a $\$ 7 /$ ton $\mathrm{CO}_{2}$ emissions price policy, as in the bottom row of Table 4 for our central scenario.

First, we vary the elasticity of demand, making it both more elastic $(\varepsilon=-0.5)$ than in the central scenario and totally inelastic $(\varepsilon=0.0)$. The main effect of a more elastic demand response is to worsen the performance of all policies except the fossil output tax relative to an emissions price. This occurs because electricity prices actually fall under the other policies, leading to increased electricity demand. More elastic demand simply worsens this counterproductive effect, while it enhances the conservation incentives of the output tax. The scenario of totally inelastic demand illustrates certain equivalencies across different policies with respect to incentives not related to conservation, as conservation does not occur with fixed demand. The emissions price and the performance standard - the two policies that embody incentives for reducing the emissions intensity of fossil fuels-become equivalent. This occurs because the performance standard no longer needs to rely on a higher implicit emissions price to make up for extra demand induced by the implicit output subsidy. Similarly, the output tax, the renewable portfolio standard, and the renewable production subsidy become equivalent, since these three policies rely solely on an increase in the price received by renewables to achieve emissions reductions when no conservation is possible.

We also explore several sensitivity analyses focused on technological change. In the first two, we vary the underlying source of technological change: one in which there is no learning (i.e., all technological progress is derived from $R \& D$ ) and another in which learning by doing is relatively more important (and R\&D less so) than in our central scenario. To make these fair comparisons, we maintain the same rate of baseline technological change as in our central scenario by adjusting the relative effectiveness of learning versus R\&D. The absence of learning by doing, and the strengthening of the effect of R\&D to compensate, makes all but the R\&D subsidy perform worse relative to the emissions price. Without learning by doing, policies that rely on expanding renewables beyond the competitive level of production simply raise costs rather than compensating for spillovers. The sensitivity results for the "high-learning" case show the opposite effects. In two other closely related scenarios, we alter the productivity of R\&D-based knowledge in lowering costs (i.e., $k_{2}=0.20$ and 0.10 ) without offsetting adjustments to learning. This alters the overall rate of technological change, but the relative performance of policies is affected similarly to the above scenarios holding the rate of innovation constant. 
Table 6

Sensitivity analyses

\begin{tabular}{|c|c|c|c|c|c|c|}
\hline$\Delta$ Surplus relative to emissions price & $\begin{array}{l}\text { Emissions } \\
\text { price }\end{array}$ & $\begin{array}{l}\text { Tradable } \\
\text { emissions } \\
\text { perform. std. }\end{array}$ & $\begin{array}{l}\text { Output tax } \\
\text { on fossil } \\
\text { generation }\end{array}$ & $\begin{array}{l}\text { Renewable } \\
\text { portfolio } \\
\text { standard }\end{array}$ & $\begin{array}{l}\text { Renewables } \\
\text { production } \\
\text { subsidy }\end{array}$ & $\begin{array}{l}\text { Renewables } \\
\text { research } \\
\text { subsidy }\end{array}$ \\
\hline Central scenario & 1.00 & 1.41 & 1.61 & 2.04 & 2.47 & 12.49 \\
\hline More elastic demand $(\varepsilon=-0.5)$ & 1.00 & 2.05 & 1.49 & 2.60 & 4.12 & 31.63 \\
\hline Inelastic demand $(\varepsilon=0.0)$ & 1.00 & 1.00 & 1.55 & 1.55 & 1.55 & 5.45 \\
\hline $\begin{array}{l}\text { No learning/higher } \mathrm{R} \& \mathrm{D}\left(k_{1}=0.0,\right. \\
\left.k_{2}=0.19\right)\end{array}$ & 1.00 & 1.44 & 1.68 & 2.26 & 2.78 & 4.27 \\
\hline $\begin{array}{l}\text { High learning/lower } \mathrm{R} \& \mathrm{D}\left(k_{1}=0.2,\right. \\
\left.k_{2}=0.13\right)\end{array}$ & 1.00 & 1.40 & 1.59 & 1.99 & 2.41 & 18.78 \\
\hline $\begin{array}{l}\text { High R\&D productivity/baseline } \\
\text { learning }\left(k_{1}=0.15, k_{2}=0.20\right)\end{array}$ & 1.00 & 1.27 & 1.43 & 1.27 & 1.73 & 4.52 \\
\hline $\begin{array}{l}\text { Low R\&D productivity/baseline learning } \\
\left(k_{1}=0.15, k_{2}=0.10\right)\end{array}$ & 1.00 & 1.50 & 1.74 & 2.61 & 3.09 & 44.46 \\
\hline Low appropriability $(\rho=0.25)$ & 1.00 & 1.41 & 1.61 & 1.93 & 2.34 & 3.49 \\
\hline High appropriability $(\rho=1.0)$ & 1.00 & 1.44 & 1.66 & 2.44 & 2.79 & 18.62 \\
\hline Shorter second stage $\left(T=10, n_{2}=6.1\right)$ & 1.00 & 1.47 & 1.70 & 2.40 & 2.86 & 19.07 \\
\hline Longer second stage $\left(T=80, n_{2}=10.0\right)$ & 1.00 & 1.35 & 1.53 & 1.71 & 2.12 & 7.95 \\
\hline $\begin{array}{l}\text { Flat natural gas electricity supply } \\
\left(c c_{2}=0\right)\end{array}$ & 1.00 & 1.50 & 3.32 & 4.17 & 4.83 & 37.02 \\
\hline
\end{tabular}

We evaluate the effect on relative policy costs of the degree of knowledge appropriability through two additional scenarios: (i) relatively low appropriability $(\rho=0.25)$ and (ii) perfect appropriability $(\rho=1.0)$. Because a lower degree of appropriability implies larger knowledge spillovers, the relative performance of any policy that directly or indirectly invests more in knowledge than the emissions price will improve as spillovers increase. Thus, with low appropriability, the costs of all the policies decrease relative to the emissions price, albeit modestly, with the R\&D subsidy experiencing the largest improvement, due to its direct effect on knowledge investment. The scenario with complete appropriability eliminates the knowledge externality entirely, thereby worsening relative performance, particularly of the R\&D subsidy.

We also explore the effect of changing the length of time in the second stage. Shortening the number of years in the second stage from 20 to $10 \mathrm{yr}$ lowers the weight on the second period. This worsens the performance of all policies relative to the emissions price, because there is less time in the future to benefit from the application of technological change, which is relied on more heavily in the other policies. Alternatively, increasing the weight on the second period (by quadrupling the number of years to 80) has the opposite effect. In both of these sensitivity cases, however, the policy ranking remains the same. The final sensitivity analysis examines a flat natural gas electricity supply function, in which case additional renewable generation displaces only natural gas-fired generation, not the more emissions intensive coal-fired generation, making it more difficult to achieve reductions.

\subsection{Combination policies for addressing technology spillovers}

The presence of knowledge spillovers in our model implies that separate policy instruments are necessary to optimally correct the climate externality and the externalities associated with both learning and R\&D. In this section we explore several scenarios with different policy combinations to assess empirically the theoretical findings of Section 2.6, while maintaining all assumptions at their values in our central case.

We first assess a scenario with a portfolio of all three policies, with the learning and R\&D subsidies set at their optimal levels and the emissions price set at a level so that the portfolio achieves the same emissions target as does a $\$ 7 /$ ton $\mathrm{CO}_{2}$ price alone (i.e., 4.8\% reduction). The optimal R\&D subsidy of $50 \%$ is straightforward to compute from Eq. (18) $(\sigma=1-\rho=0.5)$ based on the assumed appropriability rate. The optimal first-period "learning subsidy" for renewables $\left(s_{1}\right)$ depends on the future level of renewable use and other variables; it must therefore be solved numerically using Eq. (19) along with the other equations of the 
system. We find that the optimal learning subsidy is 0.3 cent $/ \mathrm{kWh}$ or $4 \%$ of the electricity price. While this amount of subsidy for learning may appear small, it is similar to the optimal R\&D subsidy if both are expressed as a percentage of revenue. That is, the optimal R\&D subsidy of $50 \%$ has a corresponding R\&D level that is $12 \%$ of renewable revenue, so that the R\&D subsidy is $6 \%$ of revenue. Nonetheless, this level of learning subsidy is much lower than the levels typically seen in practice, suggesting that, for relatively mature renewables in particular (e.g., wind), it is difficult to rationalize large subsidies on the basis of learning.

As a result of greater cost reductions and renewable penetration with the R\&D and learning subsidies, the emissions price necessary to achieve a $4.8 \%$ emissions reduction falls by $36 \%$ to $\$ 4.5 /$ ton $\mathrm{CO}_{2}$ (from $\$ 7.0 /$ ton $\mathrm{CO}_{2}$ ). Importantly, the associated cost of the policy combination actually becomes negative, and instead has a slight annual surplus of $\$ 0.04$ billion. By applying the $50 \% \mathrm{R} \& \mathrm{D}$ subsidy and $0.3 \mathrm{cent} / \mathrm{kW}$ h learning subsidy one at a time, one can see that the net surplus of the combination policy is due primarily to the $R \& D$ subsidy ( $\$ 0.20$ billion surplus annually) offsetting the cost of the emissions price, rather than the learning subsidy ( $\$ 0.02$ billion surplus annually). However, the optimal R\&D and learning subsidies lead to emissions reductions of only $1.4 \%$ and $0.3 \%$, respectively. These results demonstrate that the cost of emissions reductions through a combination of policies could be considerably lower than policies targeted solely at technology R\&D or emissions pricing. Nonetheless, the emissions reductions associated with this policy package are due primarily to the emissions price.

\section{Conclusion}

We assess different policy options for reducing $\mathrm{CO}_{2}$ emissions and promoting renewable energy and evaluate their performance with respect to economic surplus, emissions reduction, renewable energy production, and R\&D. We find that for anything beyond very small emissions reduction targets, the emissions price is the most efficient single policy for reducing emissions, since it simultaneously gives incentives for fossil energy producers to reduce emissions intensity, for consumers to conserve, and for renewable energy producers to expand production and to invest in knowledge to reduce their costs. The other policies can be described as offering different combinations of these incentives, which have different consequences for the distribution and the overall size of the burden of meeting an emissions reduction target.

The underlying process of technological change, be it through learning by doing or R\&D, turns out to be far less important than the incentives to use technology efficiently to reduce emissions. Nonetheless, the nature of technological change and the degree of knowledge spillovers do have discernable effects on the relative cost of alternative policies, which have differential effects on knowledge investment and how it occurs.

Finally, we find that an optimal portfolio of policies will include an emissions price and subsidies for technology R\&D and learning. In our empirical application we find that a policy portfolio of this type can reduce emissions at a significantly lower cost than any single policy alone, although the emissions reductions continue to be attributable to primarily the emissions price and the optimal "learning subsidy" is small. Nonetheless, it seems likely that R\&D focused on breakthrough technologies could have greater salience in the context of deeper long-term emissions reductions, although this lies beyond the scope of the current paper.

\section{Acknowledgments}

We acknowledge financial support from the U.S. Environmental Protection Agency and the Swedish Foundation for Strategic Environmental Research (Mistra). Larry Goulder, Ian Parry, Reyer Gerlach, two anonymous referees, and participants in seminars at Harvard University, London School of Economics, Statistics Norway, the University of Maryland, and Yale University provided useful comments on earlier versions of the paper.

\section{References}

[1] L. Argote, D. Epple, Learning curves in manufacturing, Science 247 (1990) 920-924.

[2] A. Bernard, C. Fischer, A. Fox, Is there a rationale for output-based rebating of environmental levies?, Resource Energy Econ. 29 (2) (2007) 83-101. 
[3] G. Biglaiser, J.K. Horowitz, Pollution regulation and incentives for pollution control research, J. Econ. Manage. Strategy 3 (1995) 663-684.

[4] L. Bottazzi, G. Peri, Innovation and spillovers in regions: evidence from European patent data, Europ. Econ. Rev. 47 (2003) $687-710$.

[5] C. Carraro, R. Gerlagh, B. van der Zwann, Endogenous technological change in environmental macroeconomics, Resource Energy Econ. 25 (1) (2003) 1-10.

[6] P.G. Downing, L.J. White, Innovation in pollution control, J. Environ. Econ. Manage. 13 (1986) 18-29.

[7] Energy Information Administration (EIA), Annual Energy Review 2001, EIA, Washington, DC, 2002.

[8] Energy Information Administration (EIA), Analysis of a 10-Percent Renewable Portfolio Standard, EIA, Washington, DC, 2003.

[9] Energy Information Administration (EIA), Assumptions to the Annual Energy Outlook 2003, EIA, Washington, DC, 2003.

[10] Energy Information Administration (EIA), Energy Market Impacts of Alternative Greenhouse Gas Intensity Reduction Goals, EIA, Washington, DC, 2006.

[11] C. Fischer, How can renewable portfolio standards lower electricity prices?, RFF Discussion Paper 06-20, Resources for the Future, Washington, DC, 2006.

[12] C. Fischer, R.G. Newell, Environmental and technology policies for climate mitigation, RFF Discussion Paper 04-05 (revised), Resources for the Future, Washington, DC, 2007.

[13] C. Fischer, I.W.H. Parry, W.A. Pizer, Instrument choice for environmental protection when technological innovation is endogenous, J. Environ. Econ. Manage. 45 (3) (2003) 523-545.

[14] L.H. Goulder (Ed.), Environmental Policy Making in Economies with Prior Tax Distortions, Edward Elgar, Cheltenham, UK, 2002.

[15] L.H. Goulder, K. Mathai, Optimal $\mathrm{CO}_{2}$ abatement in the presence of induced technological change, J. Environ. Econ. Manage. 39 (2000) 1-38.

[16] L.H. Goulder, I.W.H. Parry, R.C. Williams, D. Burtraw, The cost-effectiveness of alternative instruments for environmental protection in a second-best setting, J. Public Econ. 72 (1999) 329-360.

[17] Z. Griliches, Patent statistics as economic indicators: a survey, J. Econ. Lit. 28 (1990) 1661-1707.

[18] Z. Griliches, The search for R\&D spillovers, Scand. J. Econ. 94 (1992) 29-47.

[19] International Energy Agency (IEA), Experience Curves for Energy Technology Policy, IEA, Paris, 2000.

[20] International Energy Agency (IEA), Renewables in Global Energy Supply, IEA Fact Sheet, IEA, Paris, November, 2002.

[21] International Energy Agency (IEA), Renewables Information, IEA, Paris, 2003.

[22] A.B. Jaffe, Technological opportunity and spillovers of R\&D: evidence from firm's patents, profits and market value, Amer. Econ. Rev. 76 (5) (1986) 984-1001.

[23] A.B. Jaffe, R.G. Newell, R.N. Stavins, Technological change and the environment, in: K.-G. Mäler, J.R. Vincent (Eds.), Handbook of Environmental Economics, vol. 1, Elsevier, Amsterdam, 2003, pp. 461-516.

[24] A.B. Jaffe, R.G. Newell, R.N. Stavins, A tale of two market failures: technology and environmental policy, Ecolog. Econ. 54 (2005) $164-174$

[25] C.I. Jones, J.C. Williams, Measuring the social return to R\&D, Quart. J. Econ. 13 (114) (1998) 1119-1135.

[26] C. Jung, K. Krutilla, R. Boyd, Incentives for advanced pollution abatement technology at the industry level: an evaluation of policy alternatives, J. Environ. Econ. Manage. 30 (1996) 95-111.

[27] P.W. Kennedy, B. Laplantem, Environmental policy and time consistency: emissions taxes and emissions trading, in: S. Petrakis, E.S. Sarzetakis, A. Xepapadeas (Eds.), Environmental Regulation and Market Power: Competition, Time Consistency and International Trade, Edward Elgar, Northampton, MA, 1999.

[28] G. Klaassen, S. Miketa, K. Larsen, T. Sundqvist, The impact of R\&D on innovation for wind energy in Denmark, Germany and the United Kingdom, Ecolog. Econ. 54 (2005) 227-240.

[29] M.B. Lieberman, The learning curve and pricing in the chemical processing industries, RAND J. Econ. 15 (2) (1984) $213-228$.

[30] W.A. Magat, Pollution control and technological advance: a dynamic model of the firm, J. Environ. Econ. Manage. 5 (1978) 1-25.

[31] S.R. Milliman, R. Prince, Firm incentives to promote technological change in pollution control, J. Environ. Econ. Manage. 17 (1989) $247-265$.

[32] W.D. Montgomery, A.E. Smith, Price, quantity and technology strategies for climate change policy, in: Human-Induced Climate Change: An Interdisciplinary Assessment, Cambridge University Press, Cambridge, 2007.

[33] M.I. Nadiri, Innovations and technological spillovers, NBER Working Paper No. 4423, National Bureau of Economic Research, Cambridge, 1993.

[34] National Commission on Energy Policy (NCEP), Ending the Energy Stalemate: A Bipartisan Strategy to Meet America's Energy Challenges, NCEP, Washington, DC, 2004.

[35] National Science Foundation (NSF), Science and Engineering Indicators 2006, NSF, Washington, DC, 2006.

[36] R.G. Newell, A.B. Jaffe, R.N. Stavins, The induced innovation hypothesis and energy-saving technological change, Quart. J. Econ. 114 (1999) 941-975.

[37] R.G. Newell, W.A. Pizer, Regulating stock externalities under uncertainty, J. Environ. Econ. Manage. 45 (2003) 416 -432.

[38] K. Palmer, D. Burtraw, Electricity, Renewables, and Climate Change: Searching for a Cost-Effective Policy, Resources for the Future, Washington, DC, 2004.

[39] I.W.H. Parry, W.A. Pizer, C. Fischer, How large are the welfare gains from technological innovation induced by environmental policies?, J. Regul. Econ. 23 (3) (2003) 237-255.

[40] S. Petrakis, A. Xepapadeas (Eds.), Environmental Regulation and Market Power: Competition, Time Consistency and International Trade, Edward Elgar, Northampton, MA, 1999.

[41] D. Popp, Induced innovation and energy prices, Amer. Econ. Rev. 92 (1) (2002) 160-180. 
[42] D. Popp, ENTICE: endogenous technological change in the DICE model of global warming, J. Environ. Econ. Manage. 48 (2004) 742-768.

[43] M.E. Porter, S. Stern, Measuring the "ideas" production function: evidence from international patent output, NBER Working Paper No. 7891, National Bureau of Economic Research, Cambridge, 2000.

[44] T. Requate, W. Unold, On the incentives created by policy instruments to adopt advanced abatement technology if firms are asymmetric, J. Inst. Theoretical Econ. 157 (4) (2001) 536-554.

[45] S.H. Schneider, L.H. Goulder, Achieving low-cost emissions targets, Nature 389 (1997) 13-14.

[46] R.O. Zerbe, Theoretical efficiency in pollution control, Western Econ. J. 8 (1970) 364-376. 